\title{
Primary Pure Squamous Cell Carcinoma of Kidney Associated with Multiple Stag Horn Stones
}

This article was published in the following Dove Press journal:

International Medical Case Reports Journal

\section{Massood Hosseinzadeh (iD Sahand Mohammadzadeh (D) \\ Department of Pathology, Shiraz University of Medical Sciences, Shiraz, Iran}

\begin{abstract}
Primary Squamous cell carcinoma (SCC) of the kidney is rarely reported in the literature. It is usually associated with renal stone, and due to lack of clinical symptoms and radiological diagnostic features, patients often present at the late stages of the disease. We reported a 59-year-old woman presented with a longstanding history of flank pain and hematuria. Imaging techniques revealed enlargement of the right kidney associated with multiple staghorn stones. The patient subsequently underwent right radical nephrectomy, and histopathological examination of the mass revealed welldifferentiated keratinized squamous cell carcinoma. There was no primary source for her SCC. Although the primary SCC of the kidney is a rare entity, it should be considered in patients with longstanding renal calculi, particularly for large staghorn stones of renal pelvis. On the other hand, conventional imaging could not detect this type of malignancy. In most cases, CT and MRI play an essential role in the diagnosis of such tumors.
\end{abstract}

Keywords: squamous cell carcinoma, kidney, staghorn stone

\section{Introduction}

Primary squamous cell carcinoma of the kidney is rare cancer with poor prognosis at the time of presentation. ${ }^{1}$ There are only a few case reports in the literature, and urinary bladder and male urethra involve by SCC more frequently than the kidney. ${ }^{2}$ Although the incidence of this tumor in the kidney is rare, when a renal mass is accompanied by a longstanding renal stone, this differential diagnosis should be considered. Factors that increase the probability of SCC caused by a renal stone include chronic irritation, inflammation, and infection, which can cause squamous metaplasia in the renal pelvis epithelium. ${ }^{3}$ We reported a case of incidentally detected primary renal SCC associated with staghorn stones and severe hydronephrosis. Ultrasound (US), computed tomography (CT) characteristics are discussed along with histopathologic findings.

\section{Case Presentation}

A 59-year-old female patient presented at the hospital with flank pain and hematuria since three months ago. General and physical examinations were normal. Local examination revealed a slight tenderness on the right flank. Examination of the abdomen was unremarkable. The patient had a history of hypertension. The serum urea and creatinine levels were 14 and $1 \mathrm{mg} / \mathrm{dl}$. Urine examination revealed a $4+$ hematuria and a $1+$ proteinuria. She had no history of prior surgery.
Correspondence: Sahand

Mohammadzadeh

Department of Pathology, Shiraz

University of Medical Sciences, Shiraz,

Tel +989173078147

Fax+987I3230I7

Email mohammads@sums.ac.ir 
Ultrasound (US) evaluation revealed that the right kidney is enlarged with severe hydronephrosis and thin cortex. Shadow of multiple variable size staghorn stones demonstrated over projection of lower, mid, and upper pole and also in the renal pelvis. Shadow of two isolated solid parts measuring 55 and $35 \mathrm{~mm}$ showed within the renal pelvis and attached to the anterior wall. Renal CT revealed a $40 \mathrm{~mm}$ staghorn stone in the right renal pelvis with soft tissue mass measured $45 \mathrm{~mm}$ surrounding the mentioned staghorn stone (Figure 1). Subsequently, the right radical nephrectomy was performed.

Gross examination of the radical nephrectomy specimen revealed enlargement of the right kidney $(25 \times 14 \times 13 \mathrm{~cm})$. Cut section showed a brown colored staghorn stone in the renal calyces (Figure 2). There was ill-defined gray-white solid cystic mass replacing the renal parenchyma and renal pelvis. The mass was found invading to the perinephric fat. The rest of the kidney appeared cystic and distorted.

The microscopic examination of the hematoxylin and eosin-stained tissue revealed that a well-differentiated SCC was infiltrating the renal parenchyma, capsule, and perirenal fat (Figure 3).

Our patient in the present case developed liver metastasis after six months of primary surgical treatment, and one year after pathologic diagnosis, she died because of progressive diseases.

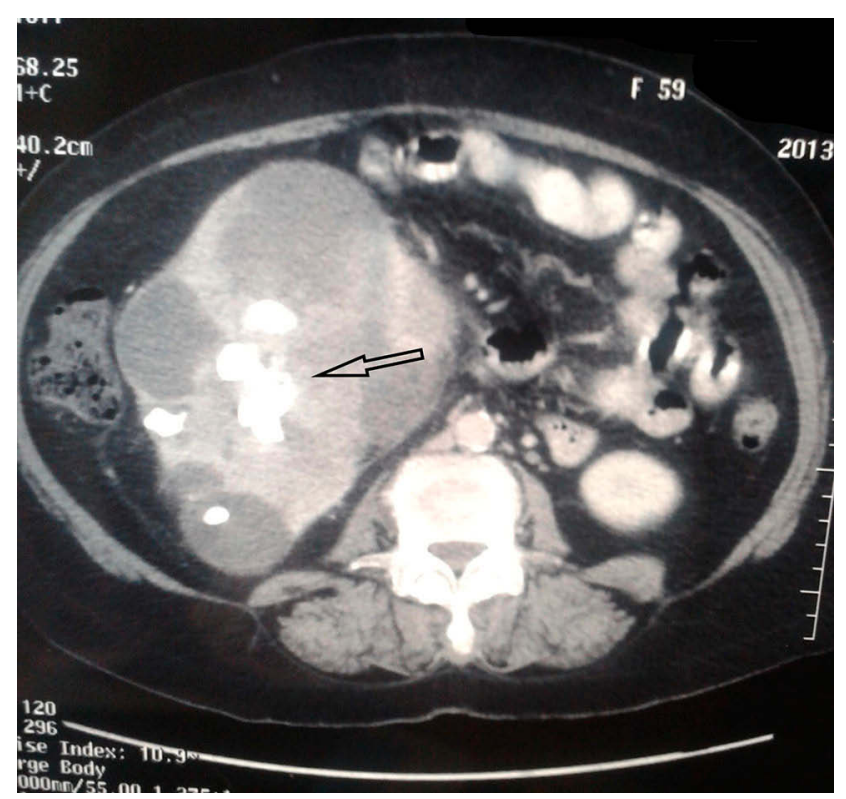

Figure I Renal CT scan revealed a $40 \mathrm{~mm}$ staghorn stone (arrow) in the right renal pelvis. Soft tissue mass measured $45 \mathrm{~mm}$ is seen surrounding the mentioned staghorn stone.

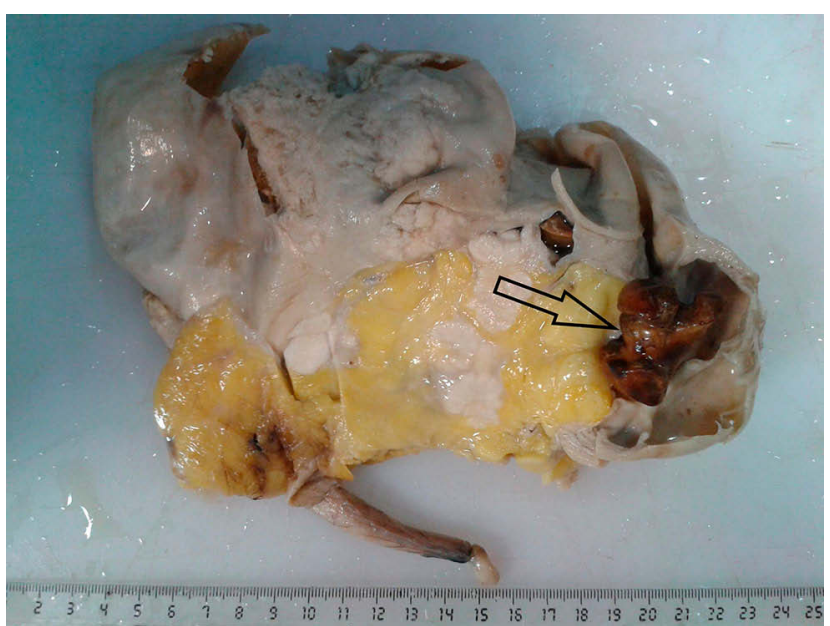

Figure 2 On gross examination of radical nephrectomy specimen, the right kidney was enlarged in size, measured $25 \times \mid 4 \times 13 \mathrm{~cm}$, and a staghorn stone (arrow) was found in cut sections.

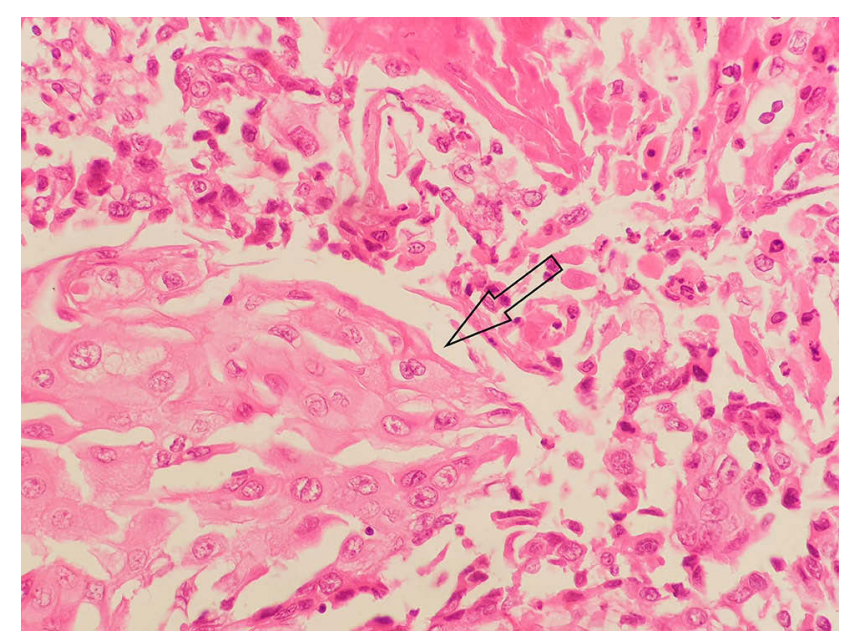

Figure 3 Microscopic examination of the hematoxylin and eosin-stained tissue revealed a well-differentiated SCC (arrow).

\section{Discussion}

The SCC is a rare malignancy of kidney, mostly present in advanced stages which its incidence is $1.4 \%$ of all renal malignancies. The literature contains few case reports, so most of the current data about SCC of the kidney are derived from small case series. In general, these tumors have a poor prognosis compare to other urinary tract malignancies. The lack of definite clinical presentation and inconclusive imaging features result in an advanced stage of presentation. ${ }^{4}$

Clinically, the SCC presents in middle age, its incidence among males and females is almost equal. Presenting symptoms include flank pain, hematuria, and abdominal mass. Significantly, due to nonspecific clinical signs and lack of specific radiological diagnostic features, most cases of the primary renal SCC are underdiagnosed. ${ }^{5,6}$ 
Radiologically, the primary SCC of the renal pelvis appears as a solid mass with hydronephrosis. The differential diagnosis of the SCC includes primary and secondary renal neoplasms. CT and MRI can play a better role in the diagnosis of these tumors, particularly in cases with renal stones. ${ }^{2}$

Histologically, the squamous cell carcinoma presents with extensive squamous differentiation, keratin pearls, and may accompany extensive necrosis. In a large case-series study, Other features such as solid and papillary patterns are observed. $^{7}$

Radical nephroureterectomy is the treatment of choice in patients with tumors limited to the kidney; however, parenchyma sparing surgeries is also proposed. Available medical literature on this rare malignant entity revealed a poor prognosis, as seen in our case. ${ }^{8}$

\section{Conclusion}

Primary squamous cell carcinoma of the kidney should be considered in patients with staghorn stones. In this setting, imaging techniques such as CT scan and MRI can help clinicians to better diagnose the tumor along with histopathological examination for confirmation.

\section{Ethics}

The study was approved by the Iran National Committee for Ethics in Biomedical Research. The patient provided written informed consent before her inclusion within the study and agreed that case details and any accompanying images could be published.

\section{Funding}

This study had no funding sources or sponsors.

\section{Disclosure}

The authors report no conflicts of interest in this work.

\section{References}

1. Jain A, Mittal D, Jindal A, et al. Incidentally detected squamous cell carcinoma of renal pelvis in patients with staghorn calculi: case series with review of the literature. ISRN Oncol. 2011;2011:1-6. doi: $10.5402 / 2011 / 620574$

2. Mardi K, Kaushal V, Sharma V. Rare coexistence of keratinizing squamous cell carcinoma with xanthogranulomatous pyelonephritis in the same kidney: report of two cases. J Cancer Res Ther. 2010;6 (3):339. doi:10.4103/0973-1482.73351

3. Karabulut A, Emir L, Gonultas M, Incel N, Germiyanoglu C, Erol DE. Squamous cell carcinoma located in the renal caliceal system: A case report and review of the literature. Turk J Cancer. 2002;32(1):20-24.

4. Berz D, Rizack T, Weitzen S, Mega A, Renzulli J, Colvin G. Survival of patients with squamous cell malignancies of the upper urinary tract. Clin Med Insights Oncol. 2012;6:CMO-S8103.

5. Palmer CJ, Atty C, Sekosan M, Hollowell CM, Wille MA. Squamous cell carcinoma of the renal pelvis. Urology. 2014;84(1):8-11. doi:10.1016/j.urology.2013.11.020

6. Verma N, Yadav G, Dhawan N, Kumar A. Squamous cell carcinoma of kidney co-existing with renal calculi: a rare tumour. BMJ Case Rep. 2011;2011(mar01 1):bcr1020103388. doi:10.1136/bcr.10.2010.3388

7. Diwan AK, Kabre RS. Primary squamous cell carcinoma of kidney: A rare case report. Int J Med Sci Res Pract. 2015;2(1):49-53.

8. Singh V, Sinha RJ, Sankhwar SN, Mehrotra B, Ahmed N. Squamous cell carcinoma of the kidney-rarity redefined: case series with review of literature. J Cancer Sci Ther. 2010;2:082-085. doi:10.4172/19485956.1000028
International Medical Case Reports Journal

\section{Publish your work in this journal}

The International Medical Case Reports Journal is an international, peer-reviewed open-access journal publishing original case reports from all medical specialties. Previously unpublished medical posters are also accepted relating to any area of clinical or preclinical science. Submissions should not normally exceed 2,000 words or 4

\section{Dovepress}

published pages including figures, diagrams and references. The manuscript management system is completely online and includes a very quick and fair peer-review system, which is all easy to use. Visit http://www.dovepress.com/testimonials.php to read real quotes from published authors. 